\title{
Diversity and abundance of caridean shrimps associated with the slimy sea plume Pseudopterogorgia americana at Pine Cay, Turks and Caicos Islands, British West Indies
}

\author{
Stephen Spotte ${ }^{1}$, Patricia M. Bubucis ${ }^{2}$ \\ ${ }^{1}$ Marine Sciences and Technology Center, The University of Connecticut at Avery Point, Groton, Connecticut 06340, USA \\ ${ }^{2}$ Sea Research Foundation, 55 Coogan Boulevard, Mystic, Connecticut 06355, USA
}

\begin{abstract}
Of 305 colonies of the slimy sea plume Pseudopterogorgia americana Gmelin, 1791 sampled at Pine Cay, Turks and Caicos Islands (British West Indies), 277 contained at least 1 caridean shrimp. Sampling occurred over 4 seasons at depths of 1.8 to $43.3 \mathrm{~m}$. The 2639 shrimps (including identifiable fragments) comprised 9 species. The predominant species in descending numbers were $P_{\text {seudocoutierea antillensis }}$ Chace, 1972, Hippolyte nicholsoni Chace, 1972, Periclimenes sp. A, and Periclimenes patae Heard \& Spotte, 1991 Populations of all 4 varied significantly by depth, but only the numbers of $P$. antillensis varied seasonally. Species diversity did not vary seasonally but was affected significantly by depth. Species abundance was unaffected by either season or depth. Females of the 4 principal species are ovigerous throughout the year. The disproportionate abundance of nonovigerous $P$. antillensis in spring could indicate variable seasonal reproduction.
\end{abstract}

KEY WORDS: Caridean shrimps - Gorgonian shrimps Pseudopterogorgia americana - Species diversity . Species abundance

Caridean shrimps that associate with gorgonians are part of the diverse and little known marine invertebrate fauna of the West Indies. Despite taxonomic interest (e.g. Borradaile 1920, Chace 1972, Criales 1980, 1981, Heard 1986. Heard \& Spotte 1991), the status of several widely distributed species remains uncertain (Criales 1984, Heard 1986, Heard \& Spotte 1991, Spotte et al. 1995).

Knowledge of gorgonian shrimp ecology has advanced even more slowly. Patton (1972) described the behavior of invertebrates associated with the gorgonian Leptogorgia virgulata at Beaufort, North Carolina (USA), including that of a caridean shrimp. Criales $(1980,1984)$ listed the gorgonian associates of several shrimps collected in the Netherlands Antilles and along the Caribbean coast of Colombia (South America). Caridean larvae are sometimes well represented in the plankton (Criales \& McGowan 1994), although whether any are gorgonian associates as adults is unknown. Spotte et al. (1995) reported on aspects of the ecology of gorgonian shrimps at Guana Island, British Virgin Islands, but their data were restricted to midsummer collections made at $<23 \mathrm{~m}$. Consequently, the results lacked the scope necessary to evaluate species diversity (richness) and abundance

Here we describe the diversity and abundance of caridean shrimps collected from gorgonians in the Turks and Caicos Islands (British West Indies) along an extensive depth gradient over all seasons. Sampling was limited to one species of gorgonian, the slimy sea plume Pseudopterogorgia americana Gmelin, 1791.

Methods. Field methods: Our study site was the forereef slope west of Pine Cay near $21^{\circ} 53^{\prime} \mathrm{N}$, $72^{\circ} 05^{\prime} \mathrm{W}$ at depths of 1.8 to $43.3 \mathrm{~m}$. Collections were made seasonally during daylight hours in November 1989 (fall), February 1989 and 1990 (winter), late April and early May 1990 (spring), and late June and early July 1990 (summer). Spotte et al. (1995) described the procedure in detail. Briefly, we dived to a predetermined depth, swam perpendicular to the forereef slope, and sampled the first Pseudopterogorgia americana colonies encountered. To collect a sample, a numbered plastic bag $(45.7 \times 91 \mathrm{~cm}, 0.08 \mathrm{~mm}$ thickness) was placed over the gorgonian, cinched at the base, and shaken vigorously to dislodge any shrimps. The bag was then pulled away while still tightly cinched, and its mouth was sealed with a rubber band. A yellow plastic tie-wrap was fastened to the base of the colony to prevent repeat sampling. Bags were used only once. Shrimps were recovered by emptying the contents of 
the water-filled bags into a $355 \mu \mathrm{m}$ sieve. The procedure eliminates the need to collect and kill numerous gorgonian colonies, and the sampling bias it introduces is minimal. A test of bias was conducted by sampling 16 gorgonian colonies as just described, then collecting the entire colonies in separate bags and examining them for remaining shrimps. No shrimps were found.

Data collection: Shrimps were identified using keys of Chace (1972) and Heard (1986). Identifiable fragments from specimens damaged during collection were counted as whole individuals (see Spotte et al. 1995). Morphologic data were taken with the aid of stereoscopic microscopes fitted with ocular micrometers. We recorded size (measured as carapace length), sex, whether or not females were ovigerous, and numbers of appendix masculina spines of males. Carapace length is defined as the distance between the tip of the rostrum and posterior dorsal margin of the carapace (Heard $\&$ Spotte 1991). To confirm the presence or absence of an appendix masculina in nonovigerous specimens, one of the second pleopods was removed, placed in a wet mount, and examined under high magnification. Shrimps lacking an appendix masculina were recorded as females. Small shrimps with rounded projections instead of appendix masculina spines were recorded as

Table 1. Seasonal frequencies of 9 species of caridean shrimps obtained from slimy sea plumes Pseudopterogorgia americana at Pine Cay, Turks and Caicos Islands

\begin{tabular}{|lrrrr|}
\hline Species & Summer & Fall & Winter & Spring \\
\hline Hippolyte nicholsoni & 157 & 239 & 250 & 262 \\
Hippolyte zostericola & 0 & 0 & 0 & 1 \\
Latreutes sp. & 0 & 1 & 0 & 0 \\
Neopontonjdes chacei & 0 & 15 & 0 & 4 \\
Periclimenes sp. A & 61 & 66 & 92 & 80 \\
Periclimenes sp. B & 0 & 1 & 1 & 1 \\
Periclimenes patae & 22 & 14 & 11 & 9 \\
Pseudocoutierea antillensis & 364 & 104 & 312 & 567 \\
Tozeuma sp. & 1 & 0 & 0 & 0 \\
\hline
\end{tabular}

males with zero spines. The sex of shrimps lacking both an appendix masculina and appendix interna was recorded as unknown.

Statistics: Samples in the field were obtained from 7 depth ranges chosen arbitrarily to facilitate the planning of dives. The use of ranges provicled a balanced design ( $\mathrm{n}=42$ to 44 ), allowing depth data in most situations to be analyzed with parametric statistics. Distributions of the dependent variables were tested for normality. Skewed variables were log-transformed (Zar 1984), but nonparametric methods were used if heteroscedasticity was still evident.

Hypotheses: We attempted to falsify 2 null hypotheses pertaining to species diversity and abundance, both with the independent variables season and depth: (1) species diversity (mean numbers of all species per gorgonian) does not vary significantly, and (2) species abundance (total numbers of shrimps per gorgonian, all species combined) does not vary significantly. A third null hypothesis pertaining to presumed reproductive status of females of the 4 principal species was evaluated by season: (3) variation is not apparent in the relative numbers of nonovigerous and ovigerous females.

A criterion for rapidly identifying the reproductive status of males is not available. Spotte et al. (1995) sectioned the testes of 35 Neopontonides chacei Heard, 1986 from Guana Island (British Virgin Islands) and reported that specimens having only 0 or 1 appendix masculina spine are least likely to be mature. In the present study, most males of the 4 principal species had 2 or more spines (see 'Results'). However, this is not direct evidence of maturity: $N$. chacei was not one of the principal species, and specimens of the others were not sectioned.

Results and discussion. We sampled 305 gorgonians over 4 seasons (70 in summer, 61 in fall, 84 in winter, 90 in spring), of which 277 contained at least one caridean shrimp; the other 28 ( $9 \%$ of the colonies) had no shrimps. We recovered 2639 shrimps (including identifiable fragments) comprising 9 species. Pseudocoutierea antillensis Chace, 1972 and Hippolyte

Table 2. Seasonal mean numbers of the 4 principal species of shrimps per colony of Pseudopterogorgia amencana with the upper range limit in parentheses (the minimum limit was always zero). The null hypothesis of no seasonal effect was tested using Kruskal-Walls' A VOVA by ranks ( $\mathrm{df}=3, \mathrm{n}=305$ ). The: $H$ statistic and its associated probability are shown in the bottom rows. No signuficance (ns) is at $\mathrm{p}>0.05$

\begin{tabular}{|lcccc|}
\hline & Hippolyte nicholsoni & Pseudocoutierea antillensis & Periclimenes sp. A & Periclimenes patae \\
\hline Summer & $2.1(20)$ & $4.9(59)$ & $0.8(8)$ & $0.3(7)$ \\
Fall & $3.9(28)$ & $1.7(16)$ & $1.1(16)$ & $0.2(5)$ \\
Winter & $3.1(27)$ & $3.9(50)$ & $1.1(14)$ & $0.1(4)$ \\
Spring & $2.9(26)$ & $6.3(90)$ & $0.9(13)$ & $0.1(3)$ \\
$H$ & 4.71 & 31.17 & 1.69 & 2.82 \\
p & ns & $<0.001$ & $n$ & $n$ \\
\hline
\end{tabular}


Table 3. Variation in caridean diversity and abundance (all species combined) with season and depth. Values are mean numbers per colony of Pseudopterogorgia americana

\begin{tabular}{|c|c|c|}
\hline & Diversity & Abundance \\
\hline \multicolumn{3}{|l|}{ Season } \\
\hline Summer & 1.6 & 8.2 \\
\hline Fall & 1.6 & 7.2 \\
\hline Winter & 1.6 & 8.3 \\
\hline Spring & 1.8 & 10.3 \\
\hline \multicolumn{3}{|c|}{ Depth range (m) } \\
\hline 0 to 4.6 & 1.5 & 7.2 \\
\hline $4.6+$ to 9.1 & 1.6 & 7.7 \\
\hline $9.1+$ to 12.8 & 1.6 & 7.1 \\
\hline 12.8 to 18.6 & 1.8 & 9.2 \\
\hline 18.6 t to 23.2 & 2.0 & 11.5 \\
\hline $23.2+$ to 28.0 & 1.4 & 11.0 \\
\hline$>28+$ & 1.5 & 6.9 \\
\hline
\end{tabular}

nicholsoni Chace, 1972 predominated, followed by Periclimenes sp. A (R. W. Heard \& S. Spotte unpubl.) and Periclimenes patae Heard \& Spotte, 1991 (Table 1). These were the 4 principal species in our samples; occurrence of the others was incidental.

Diversity and abundance: Seasonal frequencies of the 4 principal species are summarized in Table 2. Only Pseudocoutierea antillensis showed significant variation. Depth distributions are summarized in Fig. 1. Depth effects were significant in all instances. Species diversity and abundance (Table 3) were evaluated using 2-way ANOVA with season and depth as independent variables. Diversity did not vary seasonally $\left(F_{3,277}=1.04, \mathrm{p}>0.05\right)$, nor were interaction effects significant $\left(F_{18.277}=1.02, \mathrm{p}>0.05\right)$. However, depth exerted a significant effect on diversity $\left(F_{6,277}=2.49\right.$, $\mathrm{p}<0.05)$. Species abundance was unaffected by season or depth $\left(F_{3-18.248}=1.04\right.$ to $\left.1.58, \mathrm{p}>0.05\right)$.

Presumed state of maturity: Specimens of unknown sex represented $<0.31 \%$ for Pseudocoutierea antillensis, $<11 \%$ for Hippolyte nicholsoni, and $<2 \%$ for Periclimenes sp. A and Periclimenes patae. Analyses were therefore restricted to shrimps of known sex. Only 7 of 365 males of $H$. nicholsoni had less than 2 appendix masculina spines. The numbers also were low for $P$ antillensis (4 of 835), Periclimenes sp. A (12 of 120), and $P$. patae (2 of 26). Comparative counts of nonovigerous and ovigerous females of the 4 principal species were evaluated using log-linear models. Significant deviation from expected frequencies at $\mathrm{p}<0.05$ was detected only for $P$. antillensis (maximum likelihood $\left.\chi^{2}=43.43, \mathrm{df}=3, \mathrm{p}<0.001\right)$. Most of this variation occurred in spring (nonovigerous $=156$, ovigerous $=$ 41); during other seasons the disparity in numbers

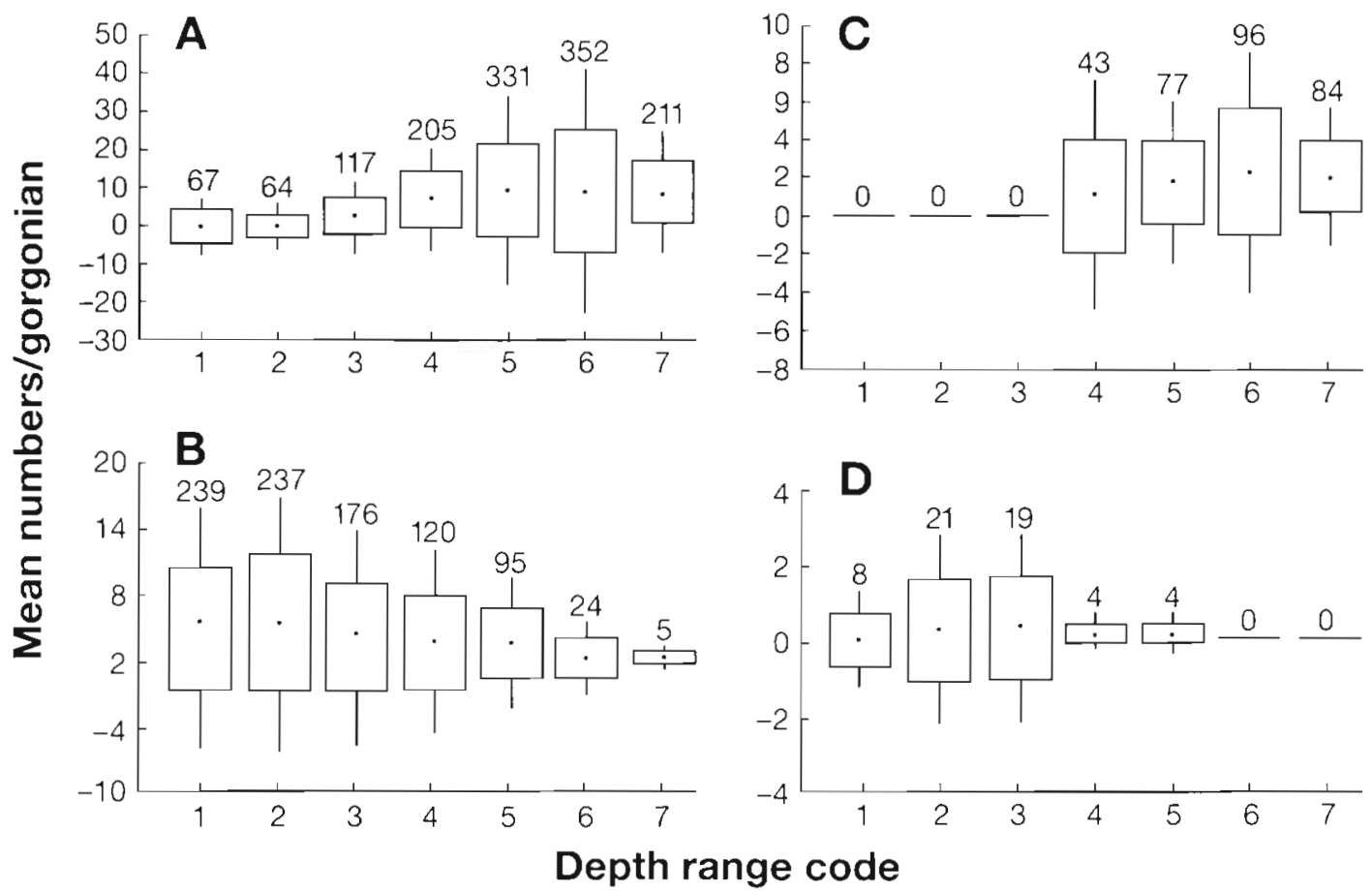

Fig. 1. Box and whisker plots showing mean numbers of shrimps per gorgonian with depth. Dark centers of the boxes are means, vertical limits of the boxes are $1 \mathrm{SD}$, vertical limits of the whiskers are $2 \mathrm{SD}$. Total n 15 shown above the upper whiskers. Depth range is in metres with code (given here in parentheses) on the horizontal axis: (1) 0 to 4.6. (2) 4.6+ to $9.1,(3) 9.1+$ to $12.8,(4) 12.8+$ to 18.6 , (5) $18.6+$ to 23.2 , (6) $23.2+$ to 28.0 , (7) $>28.0+$. All analyses by Kruska]-Wallıs' ANOVA (df $=6$, n $=305$ ). (A) Hippolyte nicholsoni $(H=102.72, \mathrm{p}<0.001)$. (B) Pseudocoutierea antillensis $(H=29.05, \mathrm{p}<0.001)$. (C) Periclimenes 5p. A (H=111.93, $\mathrm{p}<0.001)$. (D) Periclimenes patae $(H=19.21, \mathrm{p}<0.01\}$ 
between the nonovigerous and the ovigerous was not as great, perhaps indicating variable seasonal reproduction. The general trend toward continuous reproduction is consistent with findings in other tropical carideans (Bauer 1989).

Other observations: Periclimenes sp. A and Periclimenes patae are closely related, differing mainly in coloration and minor features of morphology (Heard \& Spotte 1991, unpubl.). However, the greater mean depth characteristic of Periclimenes sp. A at Pine Cay $(25.6 \mathrm{~m})$ is an ecological marker that distinguishes it from $P$. patae (Heard \& Spotte unpubl.). The roughly mirror images of Fig. $1 C$ and D illustrate this striking contrast. Periclimenes sp. A was never observed in waters shallower than $14.0 \mathrm{~m}$, and its range extended to $43.3 \mathrm{~m}$, the limit of our dives. Although $P$. patae ranged from 2.7 to $22.2 \mathrm{~m}$, its mean depth was only $9.6 \mathrm{~m}$. The minimal overlap in depth might also be an isolation mechanism that precludes social contact: Periclimenes sp. A was found on 86 different gorgonians and $P$. patae on 29 , but both species occupied the same gorgonian only twice.

The resuits reported here warrant comparison with our previous Guana Island study (Spotte et al. 1995). We found 9 species of gorgonian shrimps at both locations, 2 of which predominated. Neopontonides chacei, the principal species at Guana Island, was incidental in the Pine Cay collections (Table 1). Conversely, Pseudocoutierea antillensis, the principal species at Pine Cay, was incidental at Guana Island. The second most most numerous species at both locations was Hippolyte nicholsoni, where it occupied a shallower mean depth range than either $P$ antillensis or $N$. chacei. At both Pine Cay and Guana Island, the species occurring in the greatest numbers was distributed throughout the range of depths examined.

Acknowledgements. We thank Richard W Heard for taxonomic advice, field assistance, and suggesting this project. We also thank the members and staff of The Meridian Club and officers of the Turks and Caicos Islands Government.

This note was submitted to the editor
Supported by the Oakleigh L. Thorne Foundation. Contribution No. 283 of the Marine Sciences and Technology center and No. 96 of Sea Research Foundation.

\section{LITERATURE CITED}

Bauer RT (1989) Continuous reproduction and episodic recruitment in nine shrimp species inhabiting a tropical seagrass meadow. J Exp Mar Biol Ecol 127:175-187

Borradaile LA (1920) On a new commensal prawn. Ann Mag Nat Hist 9(5):132-133

Chace FA Jr (1972) The shrimps of the Smithsonuan-Bredin Caribbean expeditions with a summary of the West Indian shallow-water species (Crustacea: Decapoda: Natantia). Smithson Contr Zool 98: $\mathrm{x}+179$

Criales MM (1980) Commensal caridean shrimps of Octocorallia and Antipatharia in Curaçao and Bonaire with description of a new species of Neopontonides. Stud Fauna Curaçao Other Caribb Isl 61:68-85

Criales MM (1981) Two new species of Pseudocoutierea (Decapoda. Natantia. Palaemonidae) from the Colombian Caribbean. Crustaceana 41:167-181

Criales MM (1984) Shrimps associated with coelenterates, echinoderms, and molluscs in the Santa Marta region, Colombia. J Crust Biol 4:307-317

Criales MM, McGowan F (1994) Horizontal and vertical distribution of penaeidean and caridean larvae and micronektonic shrimps in the Florida Keys. Bull Mar Sci 54 $843-856$

Heard RW (1986) Pontoniıne shrimps (Decapoda: Caridea Palaemonidae) of the northwest Atlantic. I. The genus Neopontonides Holthus, 1951, with the description of $\mathrm{N}$ chacei new species, and the erection of Pseudopontonides, new genus, to receive $N$. principis Criales, 1980. J Crust Biol $6: 471-484$

Heard RW, Spotte S (1991) Pontoniine shrimps (Decapoda Caridea: Palaemonidae) of the northwest Atlantic. II Periclimenes patae, new species, a gorgonian associate from shallow reef areas off the Turks and Caicos Islands and Florida Keys. Proc Biol Soc Wash 104:40-48

Patton WK (1972) Studies on the animal symbionts of the gorgonian coral, Leptogorgia virgulata (Lamarck). Bull Mar Sci 22:419-431

Spotte S, Bubucis PM, Overstreet RM (1995) Caridean shrimps associated with the slimy sea plume (Pseudopterogorgia americana) in midsummer at Guana Island, British Virgin Islands, West Indies. J Crust Biol 15:291-300

Zar JH (1984) Biostatistical anal.ysis, 2nd edn. Prentice-Hall, Englewood Cliffs, NJ

Manuscript first received: May 29, 1995

Revised version accepted: August 23, 1995 